\title{
EFEK IMPLANTASI HORMON LHRH-a PADA IKAN BOTIA (Botia macracantha Bleeker) TERHADAP KERAGAAN PEMATANGAN GONADNYA
}

\author{
Jojo Subagja ${ }^{\star}$, Oman Komarudin ${ }^{*}$ dan Johan Effendi $\left.{ }^{* \star}\right)$
}

\begin{abstract}
ABSTRAK
Induk ikan Botia (Botia macracantha Bleeker) hasil tangkapan dari Sungai Batang hari Jambi, telah diimplantasi dengan hormon LHRH-a des Gly ${ }^{10}\left[D\right.$ - Ala ${ }^{6}$ ] Sigma Chemical pada dosis 100, 150, $200 \mu \mathrm{g} / \mathrm{kg}$ bobot badan induk. Percobaan dilakukan pada awal Januari 1995. Induk-induk botia mengalami perkembangan gonad dari muda menjadi Tingkat Kematangan Gonad (TKG) IV dan V, jika dibandingkan dengan kontrol (tanpa hormon) yang hanya berkembang sampai TKG II. Telur mencapai vitelogenesis mulai dari ukuran diameter $350 \mathrm{um}$, dan berkembang sempurna (siap ovulasi) pada diameter $800 \mu \mathrm{m}$. Perlakuan dosis hormon terendah, yaitu $100 \mu \mathrm{g} / \mathrm{kg}$ sudah cukup baik untuk pematangan ovari.
\end{abstract}

\section{ABSTRACT: The effect of LHRH-a implantation on the gonadal development of clown loach (Botia macracantha). By: Jojo Subagja, Oman Komarudin and Johan Effendi.}

Clown Loach (Botia macracantha Bleeker) brood-stocks caught from Batanghari River, Jambi were implanted with cholesterol-based pellet of LHRH-analogue des Gly ${ }^{10}\left[D\right.$-Ala $\left.{ }^{6}\right]$ Sigma Chemical at $100,150,200 \mu \mathrm{g} / \mathrm{kg}$ of body weight. After one month treatment, the female gonades developed to stages IV and V compared to the control which only reached gonade maturation stage II. The eggs started to reach vitellogenesis when they were $350 \mu \mathrm{m}$ of diameter. Vitellogenesis was completed in eggs with diameter of $800 \mu \mathrm{m}$. The minimum dosage of LHRH-a effective for gonade maturation was $100 \mu \mathrm{m} / \mathrm{kg}$.

KEYWORDS: Botia; hormone; LHRH-a; implantation; gonade maturation.

\section{PENDAHULUAN}

Ikan botia (Botia macracantha Bleeker) termasuk ikan yang sulit ditangkarkan (Hoedeman, 1975). Penelitian penangkaran yang mengarah kepada domestikasi ikan botia telah dilakukan oleh Komarudin dan Effendi (1993) mengenai pengobatan penyakit bintik putih. Kemudian Subagja dan Komarudin (1993) meneliti pematangan gonad melalui pakan buatan. Pengaruh fotoperiod diteliti oleh Satyani et al. (1994). Hasil-hasil yang dicapai baru pada tahap awal, dimana ikan botia mampu beradaptasi terhadap pakan buatan serta perkembangan gonadnya dapat mencapai TKG II dan III. Subandiyah et al. (1993) meneliti cara penampungan botia kecil dalam akuarium, kemudian Rifai dan Nurdawaty (1980) telah melakukannya dalam keramba jaring apung. Konsumsi pakan pada pemeliharaan dalam siklus tertutup diteliti oleh Hardiyati (1991), serta frekuensi pemberian pakan oleh Rachmatika (1991).

Dalam usaha penangkaran, keberhasilan akan dicapai bila ikan yang dipelihara dapat mencapai matang gonad, oleh sebab itu perlu dilakukan segala upaya untuk mencapai matang gonad. Lee et al. (1986) dan Stacey (1983) berpendapat bahwa pematangan gonad dapat dicapai melalui manipulasi lingkungan dan rangsangan hormonal. Penelitian yang dilakukan oleh Priyono et al. (1990) mengenai pemberian LHRH-a pada ikan bandeng dapat mengakibatkan ikan tersebut bertelur setiap bulan, padahal di alam ikan bandeng berkembangbiak secara musiman. Hal ini juga dilakukan oleh Harvey et al. (1985) terhadap ikan sea bass. Penelitian-

\footnotetext{
*) Peneliti pada Balai Penelitian Perikanan Air Tawar, Sukamandi

**) Litkayasa pada Balai Penelitian Perikanan Air Tawar, Sukamandi
} 
penelitian tersebut di atas dilakukan dalam upaya pematangan gonad dengan menggunakan hormon LHRH-a. Hasilnya menunjukkan bahwa pamakaian LHRH-a mampu mempercepat perkembangan gonad ikan.

Pemakaian LHRH-a dilakukan dengan cara implantasi menurut metode Lee et al. (1986). Metode ini merupakan perbaikan dari pemakaian hormon yang disuntikkan secara terus menerus dengan selang waktu 7-30 hari, seperti yang dilakukan oleh Lam (1982) pada ikan sidat. Perlakuan demikian pada ikan-ikan perairan umum praktis belum pernah dilakukan.

Tujuan penelitian ini adalah untuk mengetahui dosis optimum pemakaian hormon LHRH-a yang diimplantasikan pada ikan botia untuk mempercepat perkembangan gonadnya.

\section{BAHAN DAN METODE}

Ikan uji yang dipergunakan adalah induk botia hasil tangkapan pada bulan Desember 1994 dari Sungai Batanghari Jambi. Bobot induk berkisar antara 65-350 g per ekor dengan panjang standar $18-32 \mathrm{~cm}$. Sebelum dilakukan penelitian induk ikan terlebih dahulu diaklimatisasikan pada kondisi air resirkulasi selama 1 bulan. Pakan berupa ikan rucah dan pelet diberikan sebanyak $3 \%$ dari bobotnya.

Pemeliharaan dilakukan dalam unit resirkulasi dengan menggunakan 12 buah wadah bak serat kaca volume $1000 \mathrm{~L}$, yang masing-masing dihubungkan dengan bak pengendapan dan filter. Pompa tenggelam berkapasitas $40 \mathrm{~L} /$ menit dipergunakan untuk menaikkan air dari unit filter ke bak pemeliharaan. Setiap bak ditebari induk botia sebanyak 6 ekor. Setelah masa aklimatisasi, ikan diberi pakan buatan. Komposisi pakan buatan tersebut adalah kadar protein $35 \%$, lemak $5 \%$, kadar air maksimum $12 \%$, serat $3 \%$ dan abu $17 \%$. Pakan diberikan 3\% dari bobot biomas dengan frekuensi pemberian $3 \mathrm{kali}$, yaitu pagi, siang dan sore hari.

Pembuatan pelet hormon uji dilakukan berdasarkan metode Lee et al. (1986), yaitu dengan mencampurkan LHRH-a $500 \mu \mathrm{g}$ dengan kholesterol 47,5 mg dan ditambahkan 2,5 mg mentega tanpa garam (unsalted butter), kemudian diaduk hingga merata. Pembuatan pelet dilakukan dengan menggunakan cetakan dengan ukuran diameter lubang $1,8 \mathrm{~mm}$ dan panjang $3 \mathrm{~mm}$. Dari adonan tersebut diperoleh sebanyak 100 pelet dan setiap pelet berkadar hormon sekitar 4,8-5,2 $\mu \mathrm{g}$ (rata-rata $5 \mu \mathrm{g}$ ).

Implantasi hormon dilakukan pada induk ikan. yang telah tersedia pada masing-masing bak serat kaca dengan dosis sebagai berikut: 1) Kontrol (tanpa implantasi), 2) $100 \mu \mathrm{g}(\mathrm{P} 1)$, 3) 150 $\mu \mathrm{g}$ (P2) dan 4) $200 \mu \mathrm{g}$ (P3) per kg bobot badan ikan dan dilakukan ulangan 3 kali. Hormon diimplantasikan ke dalam tubuh ikan botia dengan menggunakan jarum (implanter) dan disisipkan ke bawah kulit (sub kutan) di bagian belakang sirip dada kanan. Arah suntikan ke bagian posterior tubuh. Implantasi diberikan hanya satu kali pada awal penelitian.

Pemeriksaan ovari secara visual, yaitu dengan jalan pembedahan dilakukan sebelum implantasi, dan pemeriksaan secara histologis dilakukan pada akhir penelitian. Pencatatan terhadap bobot ikan, panjang, dan bobot gonad juga dilakukan pada akhir penelitian. Tingkat kematangan gonad (TKG) dan perkiraan fekunditas dihitung dengan menggunakan persamaan di bawah ini (Effendie, 1979).

$$
T K G=\frac{\text { Bobot gonad }}{\text { Bobot induk }} \times 100 \%
$$

Perkiraan jumlah telur dihitung menggunakan persamaan sebagai berikut:

$$
\text { Fekunditas (jumlah telur) }=\frac{\text { Jumlah telur sampel }}{\text { Bobot ovari sampel }} \times \text { bobot ovari }
$$

Pembuatan preparat histologi menggunakan jaringan ovari hasil fiksasi larutan bufer formalin $5 \%$, dan kemudian dicetak dalam parafin dan dipotong setebal $3 \mu \mathrm{m}$ yang diambil dari bagian tengah ovari. Pewarnaan menggunakan $\mathrm{HE}$ (haematoxylin dan eosin) dan periodic acid-Sciff (PAS).

\section{HASIL DAN PEMBAHASAN}

Hasil pemeriksaan keadaan gonad ikan botia sebanyak 5 ekor yang diambil secara acak dari populasi ikan uji, yang dilakukan pada awal penelitian disajikan dalam Tabel 1. Pada tabel tersebut terlihat bahwa sebelum dilakukan implantasi hormon LHRH-a, tingkat kematangan gonadnya baru mencapai TKG I pada ikan betina. 
Ovari ikan nampak seperti benang merah dan belum terlihat adanya butir-butir telur. Pada ikan jantan, testis berbentuk seperti pipa memanjang dan tidak terlihat adanya spermatozoa.

Setelah dilakukan implantasi hormon LHRH-a dan ikan dipelihara selama 40 hari, diperoleh perubahan pada tingkat kematangan gonadnya, dari TKG I menjadi TKG V. Diameter telur serta pendugaan jumlah telur (fekunditas) disajikan dalam Tabel 2.

Perkembangan bobot induk selama penelitian tidak memperlihatkan pertambahan yang berarti, bahkan ada beberapa ikan mengalami penyusutan bobot badan. Hal ini diduga akibat infeksi dari luka bekas implantasi hormon dan ikan menjadi stres, yang berakibat ikan tidak mempunyai nafsu makan. Untuk mengurangi stres, pada saat implantasi hormon dapat digunakan obat anestesi.

Diameter telur rata-rata dari setiap perlakuan yang tertera pada Tabel 2 adalah diameter telur yang sudah mengalami vitelogenesis. Dari tabel tersebut tampak bahwa pada ikan yang tidak diimplantasi, diameter telur berkembang hanya pada kisaran 301-400 $\mu \mathrm{m}$, sedangkan pada ikan yang diimplantasi diameter telur dapat berkembang hingga kisaran 601-700 $\mu \mathrm{m}$. Pada akhir penelitian sebagian induk yang tidak dijadikan sampel untuk preparat histologi dilakukan pemijahan buatan, yaitu dengan merangsang proses ovulasi dengan penyuntikan hormon ovaprim sejumlah $1,5 \mathrm{~mL} / \mathrm{kg}$ bobot induk sebanyak 2 kali dengan interval 8 jam. Ovulasi terjadi 10 jam setelah penyuntikan ke-2 pada kondisi suhu air tempat pemijahan berkisar antara $25-28^{0} \mathrm{C}$. Pembuahan kering dilakukan, yaitu dengan jalan mengalin (stripping) ikan jantan yang langsung dibuahkan ke telur. Telur diinkubasikan pada air yang diresirkulasikan. Telur hanya dapat berkembang sampai fase blastula, yaitu 10 jam setelah pembuahan.

Tidak berkembangnya telur ke fase selanjutnya diduga ada hubungannya dengan diameter telur yang belum mencapai perkembangan sempurna, di mana diameter telur yang sudah siap ovulasi berkisar antara 700-800 $\mu \mathrm{m}$. Di lain pihak untuk mencapai keberhasilan dalam perawatan telur atau larva ikan botia, peranan manajemen kualitas air perlu mendapat perhatian utama. Salah satu parameter kualitas air yang esensial dalam proses inkubasi telur ikan hias adalah kesadahan harus rendah $(<50 \mathrm{ppm})$.

Terdapat beberapa pendapat tentang pengklasifikasian kematangan gonad ikan. Barr (1968) membagi perkembangan gonad ikan laut ke dalam 4 tingkatan. Bagenal dan Braum dalam Effendie (1979) membagi menjadi 9 tingkatan, sedangkan Combs (1969) dan Groman (1982) membagi menjadi 6 tingkatan. Penentuan perkembangan gonad ikan botia secara histologis pada penelitian ini ditentukan berdasarkan perkembangan gonad yang dikemukakan oleh Groman (1982).

Pengamatan histologi gonad ikan botia untuk masing-masing perlakuan menunjukkan bahwa gonad telah berkembang dari TKG I sampai dengan TKG VI.

Tabel 1. Ukuran dan tingkat kematangan gonad (TKG I) ikan botia hasil tangkapan dari alam Table 1. Size and gonadal somatic index (GSI I) of clown loach collected from natural water.

\begin{tabular}{ccccc}
\hline No. & $\begin{array}{c}\text { Bobot ikan } \\
\text { Fish weight } \\
(\mathbf{g})\end{array}$ & $\begin{array}{c}\text { Panjang normal } \\
\text { Standard length } \\
(\mathbf{c m})\end{array}$ & $\begin{array}{c}\text { Bobot gonad } \\
\text { Gonad weight } \\
(\mathbf{g})\end{array}$ & $\begin{array}{c}\text { Tingkat kematangan gonad } \\
\text { Gonada somatic index } \\
(\%)\end{array}$ \\
\hline & & & & \\
1. & 64.0 & 13.7 & 0.1 & 0.16 \\
2. & 205.4 & 16.6 & 0.21 & 0.10 \\
3. & 86.3 & 14.1 & 0.8 & 0.93 \\
4. & 81.1 & 14.2 & 1.0 & 1.23 \\
5. & 111.6 & 15.9 & 1.8 & 1.61 \\
\hline
\end{tabular}


Tabel 2. Ukuran telur (oosit) dan perkiraan fekunditas ikan Botia.

Table 2. Oocyte size and estimated fecundity of Botia.

\begin{tabular}{|c|c|c|c|c|c|c|c|}
\hline \multirow[t]{2}{*}{$\begin{array}{l}\text { Perlakuan } \\
\text { Treatment }\end{array}$} & \multirow[t]{2}{*}{$\begin{array}{c}\text { Sampel telur } \\
\text { Egg sample }\end{array}$} & \multicolumn{5}{|c|}{$\begin{array}{c}\text { Distribusi telur dari masing-masing kelompok } \\
\text { diameter (Eggs distribution per group of } \\
\text { diameter size) }\end{array}$} & \multirow{2}{*}{$\begin{array}{l}\text { Perkiraan } \\
\text { fekunditas } \\
\text { Estimated } \\
\text { fecundity }\end{array}$} \\
\hline & & $\begin{array}{c}200-300 \\
\mu \mathrm{m}\end{array}$ & $\begin{array}{c}301-400 \\
\mu \mathrm{m}\end{array}$ & $\begin{array}{c}\text { 401-500 } \\
\mu \mathrm{m}\end{array}$ & $\begin{array}{c}501-600 \\
\mu \mathrm{m}\end{array}$ & $\begin{array}{c}601-700 \\
\mu \mathrm{m}\end{array}$ & \\
\hline $\begin{array}{l}\text { Kontrol } \\
\text { Control }\end{array}$ & $\begin{array}{l}\text { A } \\
\text { B } \\
\text { C }\end{array}$ & $\begin{array}{l}64 \\
72 \\
76\end{array}$ & $\begin{array}{l}36 \\
28 \\
24\end{array}$ & & & & \\
\hline P 1.1 & $\begin{array}{l}\text { A } \\
\text { B } \\
\text { C }\end{array}$ & $\begin{array}{l}44 \\
56 \\
55\end{array}$ & $\begin{array}{l}36 \\
11 \\
26\end{array}$ & $\begin{array}{l}20 \\
33 \\
16\end{array}$ & & & 18,700 \\
\hline P 1.2 & $\begin{array}{l}\text { A } \\
\text { B } \\
\text { C }\end{array}$ & $\begin{array}{l}65 \\
68 \\
53\end{array}$ & $\begin{array}{l}18 \\
21 \\
24\end{array}$ & & $\begin{array}{c}14 \\
6 \\
12\end{array}$ & $\begin{array}{c}3 \\
5 \\
11\end{array}$ & 17,268 \\
\hline P 1.3 & $\begin{array}{l}\text { A } \\
\text { B } \\
\text { C }\end{array}$ & $\begin{array}{l}81 \\
88 \\
76\end{array}$ & $\begin{array}{l}12 \\
11 \\
16\end{array}$ & & $\begin{array}{l}7 \\
1 \\
8\end{array}$ & & 19,957 \\
\hline P 2.1 & $\begin{array}{l}\text { A } \\
\text { B } \\
\text { C }\end{array}$ & $\begin{array}{l}77 \\
85 \\
52\end{array}$ & $\begin{array}{c}10 \\
8 \\
26\end{array}$ & & $\begin{array}{c}10 \\
3 \\
17\end{array}$ & $\begin{array}{l}3 \\
4 \\
5\end{array}$ & 17,890 \\
\hline P 2.2 & $\begin{array}{l}\text { A } \\
B \\
C\end{array}$ & $\begin{array}{l}65 \\
56 \\
55\end{array}$ & $\begin{array}{l}23 \\
31 \\
33\end{array}$ & & $\begin{array}{c}10 \\
11 \\
8\end{array}$ & $\begin{array}{l}2 \\
2 \\
4\end{array}$ & 21,000 \\
\hline P 2.3 & $\begin{array}{l}\text { A } \\
\text { B } \\
\text { C }\end{array}$ & $\begin{array}{l}43 \\
38 \\
60\end{array}$ & $\begin{array}{l}11 \\
40 \\
11\end{array}$ & & $\begin{array}{l}11 \\
14 \\
11\end{array}$ & $\begin{array}{c}35 \\
8 \\
18\end{array}$ & 14,300 \\
\hline P 3.1 & $\begin{array}{l}\mathrm{A} \\
\mathrm{B} \\
\mathrm{C}\end{array}$ & $\begin{array}{l}55 \\
38 \\
33\end{array}$ & $\begin{array}{l}27 \\
31 \\
40\end{array}$ & & $\begin{array}{c}8 \\
15 \\
13\end{array}$ & $\begin{array}{l}10 \\
16 \\
14\end{array}$ & 8,450 \\
\hline P 3.2 & $\begin{array}{l}\text { A } \\
\text { B } \\
\text { C }\end{array}$ & $\begin{array}{l}80 \\
71 \\
64\end{array}$ & $\begin{array}{l}13 \\
23 \\
24\end{array}$ & & $\begin{array}{c}7 \\
5 \\
10\end{array}$ & $\begin{array}{l}1 \\
2\end{array}$ & 10,945 \\
\hline P 3.3 & $\begin{array}{l}\mathrm{A} \\
\mathrm{B} \\
\mathrm{C}\end{array}$ & $\begin{array}{l}54 \\
57 \\
57\end{array}$ & $\begin{array}{l}26 \\
20 \\
16\end{array}$ & & $\begin{array}{l}14 \\
20 \\
19\end{array}$ & $\begin{array}{l}6 \\
3 \\
8\end{array}$ & 11,230 \\
\hline
\end{tabular}

$\mathrm{P} 1=$ dosis hormon $100 \mu \mathrm{g} / \mathrm{kg}$ bobot ikan, $\mathrm{P} 2=150 \mu \mathrm{g} . \mathrm{kg}$ bobot ikan, $\mathrm{P} 3=200 \mu \mathrm{g} / \mathrm{kg}$ bobot ikan, $\mathrm{A}=$ sampel telur bagian depan, $\mathrm{B}$ = sampel telur bagian tengah, $\mathrm{C}=$ sampel telur bagian belakang, jumlah telur contoh 100 butir.

$P 1=$ hormone dosage at $100 \mu \mathrm{g} / \mathrm{kg}$ fish weight, $P 2=150 \mu \mathrm{g} / \mathrm{kg}$ fish weight, $P 3=200 \mu \mathrm{g} / \mathrm{kg}$ fish weight, A= egg sample from anterior part of ovary, $B=\mathrm{egg}$ sample from medium part of ovary, $C=\mathrm{egg}$ sample from posterior part of ovary, number of sampled egg = 100$)$. 
Hasil pemeriksaan terhadap preparat histologi gonad ikan botia adalah sebagai berikut.

\section{Tingkat Kematangan Gonad I}

Pada TKG I ini sel telur baru mengalami perbanyakan dari sel epitel ovari dan membentuk oogonia. Kumpulan oogonia berbentuk bulat yang hanya tampak dilapisi satu dinding epitel, sitoplasma berwarna merah jambu dengan nukleus besar (Gambar 1A). Keadaan ini dijumpai pada saat pemeriksaan gonada awal penelitian.

\section{Tingkat Kematangan Gonad II}

Pada kondisi ini oogonia berkembang menjadi oosit dengan sitoplasma bertambah besar dan nuleus terletak di tengah-tengah. Selama perkembangan, oosit ditutupi satu baris epitel. Diameter oosit berkisar antara 100-150 $\mu \mathrm{m}$ (Gambar 1B).

\section{Tingkat Kematangan Gonad III}

Fase ini adalah fase perkembangan dinding sel. Oosit semakin membesar dan mulai tampak inti sel, sitoplasma berwarna biru, merupakan awal/persiapan vitelogenesis, diameter telur berkisar antara 200-300 $\mu \mathrm{m}$ (Gambar 1C). Induk ikan botia yang tidak diimplantasi yang mencapai TKG III rata-rata $70 \%$, sedangkan pada perlakuan implantasi dengan dosis hormon LHRH-a 100,150 dan $200 \mu \mathrm{g} / \mathrm{kg}$ diperoleh TKG-nya masing-masing $65 \%, 58,5 \%$ dan $56,6 \%$.

\section{Tingkat Kematangan Gonad IV}

Membran inti mulai tampak berwarna terang melingkari inti sel. Inti berwarna merah jambu sedangkan sitoplasma berwarna biru akan tetapi lebih terang dibandingkan dengan TKG II dan III. Pada fase ini vitelogenesis berlangsung dan mulai terbentuk granula dan vakuola pada sitoplasma, serta mulai terbentuk zona radiata yang berasal dari sel epitel dengan diameter telur antara 300-500 $\mu \mathrm{m}$ (Gambar 1D).

\section{Tingkat Kematangan Gonad V}

Pada fase ini nukleus tampak jelas dengan granula yang kasar. Sitoplasma berwarna biru sedangkan nukleus berwarna merah jambu agak cerah dengan dinding dan cairannya mulai meng. alami degenerasi. Lapisan zona radiata lebih jelas tersusun dari sel berbentuk kubus dan sel tiang. Diameter telur berkisar antara 500-600 $\mu \mathrm{m}$ (Gambar 1E)

\section{Tingkat Kematangan Gonad VI}

TKG VI adalah fase maksimum perkembangan oosit, di mana sudah mengalami perkembangan optimal dengan vakuola berukuran besar dan jumlahnya semakin banyak. Nukleus serta granula tampak lebih jelas memenuhi sitoplasma. Dinding folikel terdiri atas zona radiata, teka interna dan eksterna. Pada bagian tertentu dari teka terdapat epitel yang menipis membentuk mikrofil. Diameter telur mencapai kisaran antara 600-700 $\mu \mathrm{m}$ (Gambar 1F).

Di perairan alam (in situ) biasanya ikan botia mencapai matang gonad dan berpijah pada awal musim penghujan, yaitu bulan Oktober-Desember (Dinas Perikanan DATI I Jambi, 1993). Sesuai dengan hal tersebut, pada penelitian ini terlihat dari induk ikan yang dibedah sebelum penelitian baru mencapai TKG I. Pada saat berbiak ikan botia temasuk ikan yang melepaskan semua telurnya secara serempak. Dengan demikian siklus reproduksi ikan botia membutuhkan waktu minimal satu tahun.

Dengan perlakuan implantasi hormon LHRH-a selama satu bulan perkembangan gonad ikan botia dapat dipacu, di mana oosit pada TKG I (pada awal penelitian) berkembang menjadi TKG V dan VI. Peranan LHRH-a dalam mempercepat perkembangan gonad ikan bandeng juga di tempuh dalam waktu satu bulan (Priyono et al., 1990).

Hasil analisis ragam terhadap persentase oosit yang mengalami vitelogenesis (mulai ukuran diameter telur $350 \mu \mathrm{m}$ ) tidak berbeda nyata $(\mathrm{P}>0,05)$ untuk masing-masing perlakuan. Dengan demikian dosis LHRH-a terendah, yaitu $100 \mu \mathrm{g} / \mathrm{kg}$ bobot badan, sudah efektif untuk memacu perkembangan gonad ikan botia.

Kualitas kimia dan fisika air media selama penelitian berlangsung masih dalam kisaran yang optimal, untuk mendukung kehidupan ikan (Tabel 3). 

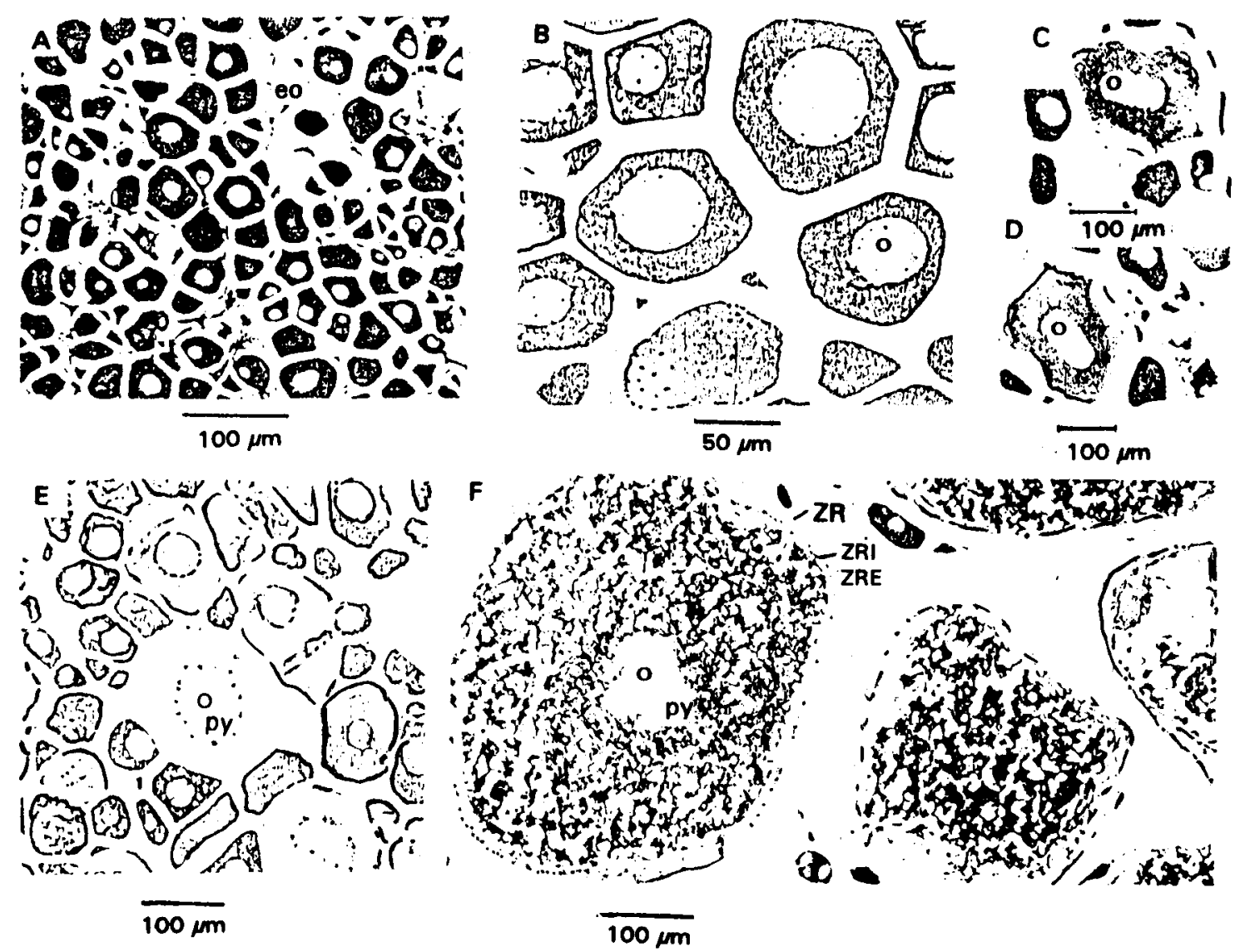

Gambar 1. Hasil pengamatan histologi (pewarnaan HE; perbesaran $400 \mathrm{X}$ ) dari fase perkembangan primer dan sekunder telur ikan Botia setelah diimplantasi hormon LHRH-a A) Tingkat Kematangan Gonad (TKG) I, pembentukan sel-sel epitel menjadi oogonia (eo), oosit (o). B) TKG II awal perkembangan perinukleus, oosit (o). C) TKG III mulai tampak dinding inti sel, oosit (o). D) TKG IV fase perkembangan akhir perinukleus, dinding inti berkembang, oosit (o). E) TKG V awal fase perkembangan sekunder, oosit bervariasi, droplet lemak, oosit (o), granula protein dalam inti. F) TKG VI granula protein inti primer (py), zona-radiata (ZR), zona radiata interna (ZRI), zona radiata eksterna (ZRE).

Figure 1. Histological observation (HE coloring; magnification 400) on primary and secondary egg development of Botia after implanted with LHRH-a hormone. A) In gonad maturation stage I, ephytel cell developed to oogonia (eo), oocyte (o); B) In gonad maturation stage II early development of perinucleus, oocyte (o); C) In gonad maturation stage III beginning appearance of nucleus shell, oocyte (o); D) In gonad maturation stage IV late development of perinucleus, nucleic shell developed, oocyte (o); E) In gonad maturation stage $V$ secondary phase development, oocyte varied, fat droplet, oocyte (o), protein granule; $F)$ In gonad maturation stage VI, primary protein granule $(p y)$ zone radiate $(Z R)$, zone radiate interna (ZRI), zone radiate externa (ZRE). 
Tabel 3. Kualitas air pada sistem resirkulasi.

Table 3. Water quality the recirculation system.

\begin{tabular}{llcc}
\hline \multicolumn{1}{c}{$\begin{array}{c}\text { Sifat fisika dan kimia air } \\
\text { Physical and chemical characteristics of }\end{array}$} & $\begin{array}{c}\text { Mater } \\
\text { Minimum }\end{array}$ & $\begin{array}{c}\text { Maksimum } \\
\text { Maximum }\end{array}$ \\
\hline Oksigen terlarut (DO) & $(\mathrm{ppm})$ & 7.6 & 9.6 \\
Karbon dioksida bebas (Free carbon dioxide) & $(\mathrm{ppm})$ & 0 & 7.19 \\
$\mathrm{pH}$ & & 7.5 & 8.82 \\
$\mathrm{Alkalinitas}$ (Alkalinity) eq. $\mathrm{CaCO}_{3}$ & $(\mathrm{ppm})$ & 92.62 & 253.80 \\
$\mathrm{NH}_{3}$ total & $(\mathrm{ppm})$ & 0.012 & 0.051 \\
$\mathrm{NO}_{2}$ total & $(\mathrm{ppm})$ & 0.165 & 0.251 \\
$\mathrm{Suhu}^{\text {air }(\text { Water temperature) }}$ & $\left({ }^{\circ} \mathrm{C}\right)$ & 28.0 & 33.3 \\
\hline
\end{tabular}

\section{KESIMPULAN}

Dari hasil penelitian implantasi hormon LHRH-a terhadap keragaan pematangan gonad ikan botia dapat disimpulkan sebagai berikut:

1. Penggunaan LHRH-a dosis $100 \mu \mathrm{g} / \mathrm{kg}$ bobot induk cukup efektif untuk memacu pematangan gonad ikan botia di luar musim pemijahannya.

2. Vitelogenesis (pembentukan granul kuning telur pada sitoplasma) sudah dimulai pada telur berdiameter $350 \mu \mathrm{m}$.

\section{DAFTAR PUSTAKA}

Barr, W.A. 1968. Patterns of ovarian activity. In E.J.W Barrington and C.B. Jorgensen.(eds) Perspectives in endocrinology hormones in the liver of lower vertebrates New York Academic Press, pp 164-238.

Combs, R.M. 1969. Embryogenesis, histology and organology of the ovary of Brevoortia patronus, Gulf Research Report 2: 333-434

Dinas Perikanan Propinsi DT I Jambi. 1993. Identifikasi dan inventarisasi plasma nutfah perikanan perairan umum perikanan Jambi, 119 hal.

Effendie.M.I. 1979. Metode biologi perikanan. Yayasan Dewi Sri Bogor, 140 hal.

Hardiyati, R.K. 1991. Anakan ikan botia pada sistem perairan tertutup, Pross. Sem. Hasil Penl.Peng. Sumber Daya Hayati. LIPI. 177-181.

Harvey, B.; Nacario, .J.; Crim, L.W.; Juario J.V; and Marte, C.L. 1985. Induced spawning of sea bass
(Lates calcarifer), and Rabbitfish Siganus guttatus after implantation of pelleted LHRH-a, Aquaculture 47:53-59

Groman, D.B. 1982. Histology of the stripped bass. American Fisheries Society, Bethesda, Maryland $116 \mathrm{p}$.

Hoedeman, J.J. 1975. Naturalist guide to freshwater aquarium fish. Sterling Publishing Co, Inc, New York 421-440 p.

Komarudin, O. dan J. Effendi. 1993. Pengobatan penyakit ichyopthyrriasis pada ikan botia. Pros Hasil Penel. Perikanan Air Tawar (in press).

Lam, T.J. 1982. Application of endocrinology to fish culture Can. J.Fish Aqua 39, 111-137 p.

Lee, C.S.; C.S. Tamaru; and C.D. Kelly 1986. Technique for making chorionic-release LHRH-a 17 alpha methyltestosteron pellets for intramuscular implantation in fishes. Aquaculture, 59:161-168.

Priyono, A.; G. Sumarsa; Z.I. Azwar. 1990. Implantasi hormon LHRH-a dan atau 17 alfa methyltestoteron untuk pematangan gonad ikan bandeng, Bul. Pen. Bud. Pantai. 6(1): 20-23.

Rifai, S.A dan S. Nurdawaty. 1990. Penampungan ikan hias botia (Botia macracantha) sistem sangkar di danau. Bull. Penel. Perik. Darat. 9:(1): 39-42.

Rachmatika, I. 1991. Pengaruh frequensi pemberian pakan cacing tubifex untuk botia dalam sistem aliran tertutup. Dalam Pros.Sem.Hasil Penl. Peng. Sumber Daya Hayati LIPI, 171-181.

Satyani, D.; S. Sumastri dan O. Komarudin. 1994. Pematangan gonad calon induk ikan botia dengan photoperiod berbeda. Dalam Pros. Hasil Seminar Perikanan Air Tawar, 1993. 185-193. 
Subagja, J. dan O. Komarudin. 1994. Pematangan gonad ikan Botia macracantha dalam sistem resirkulasi. Dalam Pros. Seminar hasil penelitian Th 1993. Rapat Kerja Teknis Balitkanwar. 248-252.

Subandiyah, S.; J. Subagja dan P. Yuliati. 1993. Pengaruh kombinasi pakan buatan dan alami terhadap pertumbuhan ikan botia. Dalam Pros. Hasil Penel.Perikanan Air Tawar. 257- 259.

Stacey, N.E. 1983. Control of timing of the ovulation by exogenous and endogenous factor. In G.Wotton Potts and R.J Wottons (eds) Fish Reproduction, Strategic and Tactic. Academic Press London, 207 $.222 \mathrm{p}$. 